
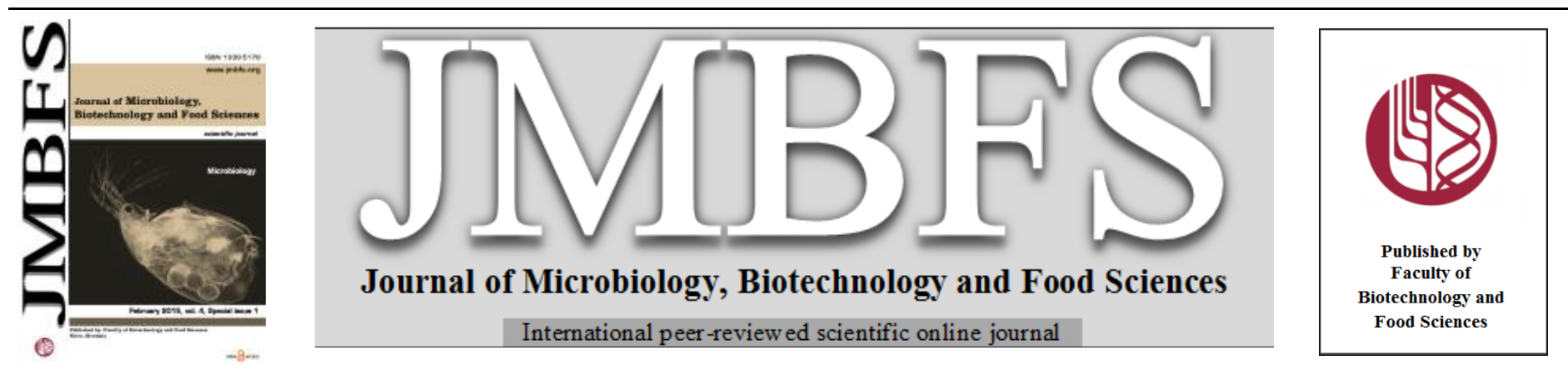

\title{
ANTIMICROBIAL ACTIVITY OF ROSA CANINA FLOWERS AGAINST SELECTED MICROORGANISMS
}

\section{Katarina Rovnál, Jana Petrová ${ }^{2}$ Margarita Terentjeva ${ }^{3}$, Jana Černá ${ }^{1}$, Miroslava Kačániová ${ }^{2} *$}

\section{Address(es):}

${ }^{1}$ Slovak University of Agriculture in Nitra, Horticulture and Landscape Engineering Faculty, Department of Green's Biotechnics, Trieda Andreja Hlinku 2, 949 76, Nitra, Slovakia.

${ }^{2}$ Slovak University of Agriculture in Nitra, Faculty of Biotechnology and Food Sciences, Department of Microbiology, Trieda Andreja Hlinku 2, 949 76, Nitra, Slovakia.

${ }^{3}$ Latvia University of Agriculture, Faculty of Veterinary Medicine, Institute of Food and Environmental Hygiene, K. Helmaņa iela 8, LV 3007, Jelgava, Latvia.

*Corresponding author: miroslava.kacaniova@gmail.com

doi: 10.15414/jmbfs.2015.4.special1.62-64

\section{ARTICLE INFO}

Received 2. 12. 2014

Revised 18. 12. 2014

Accepted 6. 1.2015

Published 2. 2. 2015

\section{Regular article}

open 2 access

\section{ABSTRACT}

Rosa canina flowers were screened against various plant pathogenic microbial strains to study the antimicrobial properties of the plant. Ethanolic and methanolic extracts of flowers were screened applying agar well diffusion method against two Gram-negative bacteria including Escherichia coli CCM 3988 and Pseudomonas aeruginosa CCM 1960 and three microscopic filamentous fungi strains Aspergillus niger, Fusarium culmorum and Alternaria alternata, respectively. The best antimicrobial effect of ethanolic extract of Rosa canina flowers was found against Pseudomonas aeruginosa and the best antimicrobial effect of methanolic extract of Rosa canina flowers was found against Escherichia coli.

Keywords: Bacteria, microscopic filamentous fungi, antimicrobial activity, flowers of Rosa canina

\section{INTRODUCTION}

Medicinal plants is a source of basic raw materials for different industries such as pharmaceutical, cosmetic, perfumery, food, etc. The whole plant or its different parts may be of high value because of its therapeutic, medicinal, aromatic or savory qualities. They also play a vital role as an antimicrobial agent. There has been resurgence in the consumption and demand for medicinal plants because the resistance to antimicrobial agents such as antibiotics is emerging worldwide of variety of organisms and thus multiple drug resistant organisms pose serious threats to society. Hence, plant derived antimicrobial agents have received considerable attention in recent years (Sathiyaet al., 2008).

The pseudo-fruit of Rosa canina L. (Rosaceae) consists of a u-shaped receptacle with numerous achenes inside. The pseudo-fruit is rich in Vitamin $\mathrm{C}$ and their fresh and dried products are frequently used as an herbal tea (Montazeri $\boldsymbol{e t}$ al., 2011; Kerényi-Nagy et al., 2013). Rose pseudo-fruit is traditionally apply for the prevention and therapy of common cold, prevention of inflammation of the gastric mucosa and gastric ulcer, and for gallstones and biliary complaints. It is also used as a laxative, for disorders of the kidney and the lower urinary tract. In addition, it is used as a diuretic in case of dropsy. Likewise, it is used as an astringent (Deliorman Orhan et al., 2007; Wenzig et al., 2009; Fecka, 2009) and in the treatment of various inflammatory diseases as a source of Vitamin C (Chrubasik et al., 2006). Rose pseudo-fruit, which is marketed as a food supplement, has been shown to reduce osteoarthritis symptoms in clinical trials (Rein et al., 2004).

Some works have been published on chemical composition of some rose species fruits, especially on Rosa canina. It was previously reported that $R$. canina fruits, which contain high phenolic and flavonoid contents, have antioxidant antimutagenic and anticarcinogenic effects. Passing the different biochemical assays, including the ability to reduce the hydroxyl radical south $(\mathrm{OH} \bullet)$, hydrogen peroxide $\left(\mathrm{H}_{2} \mathrm{O}_{2}\right)$, Trolox equivalent antioxidant capacity, metal ion chelating and free radical scavenging activity, gives to fruits of $R$. canina the natural antioxidant properties and could replace the synthetic additives (Kilicgun and Altiner,2010; Egea $\boldsymbol{e t}$ al., 2010). The antioxidant activity of leaf extracts of $R$. canina were also reported after treatment with ABTS test, 2,2'-azinobis (3ethylbenzthiazoline-6-acid) (ABTS) and 2,2-diphenyl-1-picryhydrazyl (DPPH) methods (Ghazghazi et al., 2010). Additionally the recent studies revealed that $R$. canina extracts were effective for the inhibition of growth and biofilm formation in methicillin-resistant Staphylococcus aureus (MRSA) (Serteser et al., 2008; Quave et al., 2008).
Methanol, dichloromethane and $n$-hexane extracts of rose hip seed were assessed for their antibacterial activity against 11 pathogenic Gram-positive and Gramnegative bacterial species. Only the methanol extract demonstrated weak antibacterial effect and only against E. coli 8110 (Kumarasamy et al., 2002). Dried rose petals were homogenized in $70 \%$ acetone and filtered. The acetone extract was then concentrated and extracted with diethylether, butanol and ethylacetate, respectively. The ethyl acetate extract had the highest minimal inhibitory concentration (MIC) of ß-lactams against methicillin-resistant Staphylococcusaureus and also reduced the MICs of benzylpenicillin and ampicillin. Among two polyphenols were isolated tellimagrandin I was more effective than rugosin $\mathrm{B}$ and had synergistic effect to oxacillin in reducing the MIC in methicillin-resistant Staphylococcus aureus. The MIC of oxacillin was reduced from $128-512 \mu \mathrm{g} / \mathrm{mL}$ to $1-2 \mu \mathrm{g} / \mathrm{mL}$, restoring the effectiveness of $\beta$ lactams against methicillin-resistant Staphylococcus aureus. Tellimagrandin I also significantly reduced the MIC of tetracycline in some strains of methicillinsensitive Staphylococcus aureus (Shiota et al., 2000). The group also showed that inactivation of penicillin binding proteins is involved in this mechanism of action as well as a partial inhibition of B-lacatamase. Since the chelating agents and radical scavengers tested did not affect the MICs of oxacillin in the bacteria the authors concluded that the activity of constituents is not exerted via an antioxidative effect (Shiota et al., 2004). The petroleum, ethanol and aqueous extracts investigated in the study on the cytotoxic effects of rose hip seed (Trovato et al., 1996) and they were also tested for their antimycotic activity on strains of Candida albicans. The ethanol rose hip seed extract had modest, but significant antimycotic effect (Trovatoet al, 2000).

Based on this, the present study was aimed at evaluating the antibacterial effects of Rosa canina flowers against plant pathogens.

\section{MATERIAL AND METHODS}

\section{Plant material}

The flowers of $R$. canina, which is growing in wild in Slovakia, were collected in May 2013 from Nitra-Zobor, Vrbové-Baraní dvor, Rišňovce, Modra pažit’ places in Slovakia. 


\section{Preparation of plant extracts}

After drying, flowers of Rosa canina were crushed and $10 \mathrm{~g}$ of material was soaked separately in $100 \mathrm{~mL}$ of ethanol p.a. (96\%, Sigma, Germany) during two weeks at room temperature in the dark. Exposure to sunlight was avoided to prevent the degradation of active components. Then the ethanolic plant extracts were subjected to evaporation under reduced pressure at $40{ }^{\circ} \mathrm{C}$ in order to remove the ethanol (Stuart RE300DB rotary evaporator, Bibby scientific limited, UK, and vaccum pump KNF N838.1.2KT.45.18, KNF, Germany). For the antimicrobial assay, the drying flowers extracts were dissolved in ethanol and methanol, which were used as the solvents.

\section{Test microorganisms}

Five strains of microorganisms were tested in this research. Two Gram-negative bacteria include Escherichia coli CCM 3988 and Pseudomonas aeruginosa CCM 1960, three microscopic filamentous fungi strain Aspergillus niger, Fusarium culmorum and Alternaria alternata. Bacterial strains were collected from the Czech Collection of Microorganisms (Masaryk University, Czech Republic)and microscopic filamentous fungi were collected from the Department of Microbiology, Faculty of Biotechnology and Food Sciences, Slovak University of Agriculture in Nitra, Slovakia. The bacterial isolates were cultivated in Mulle Hinton broth (Imuna, Slovakia) at $37{ }^{\circ} \mathrm{C}$ for 24 hours and microscopic filamentous fungi culture was cultivated in Malt extract broth (Biomark, India) at $30{ }^{\circ} \mathrm{C}$ for 24 hours.

\section{Antimicrobial activity with disc diffusion method}

Antimicrobial activity of flowers extract was determined using a disc diffusion method. Briefly, a $100 \mu \mathrm{l}$ of the test bacteria and microscopic fungi were grown in $10 \mathrm{ml}$ of fresh media until they reached a count of approximately $10^{5}$ cells. $\mathrm{ml}^{-1}$ An amount of $100 \mu 1$ of the microbial suspension was spread onto Mueller Hinton agar and Malt agar plates (Biomark, India). The extracts were tested using $9 \mathrm{~mm}$ sterilized filter paper discs impregnated with the tested suspension. The diameters of the inhibition zones were measured in millimeters. All measurements were to the closest whole millimeter. Each antimicrobial assay was performed in at least triplicate. Filter discs impregnated with a $10 \mu \mathrm{l}$ of distilled water were used as a negative control.

\section{RESULTS AND DISCUSSION}

In our study the best antimicrobial effect of Rosa canina flower ethanolic extract was found against Gram-negative bacteria - Pseudomona aeruginosa and Escherichia coli than against microscopic fungi - Aspergillus niger, Fusarium culmorum and Alternaria alternate (Figure 1).

Extract from Rosa canina L. petals (rose red) strikingly increases the effectiveness of several antibiotics against methicillin-resistant Staphylococcus aureus (Rossnagel and Willich, 2001). Trovato et al., 2000 study has demonstrated strong activity of Rosa canina extract against Candida albicans strains isolated from clinical samples obtained in case of acute vaginitis. Additionally, the effect of anthocyanin preparation isolated from the flower petals of Rosa canina was studied in Chinese hamster fibroblasts and Vicia faba seedlings in respect to cytogenetic damage and mouse survival and there were pronounced radioprotective effects demonstrated without any toxic consequences (Trovato et al 2000).
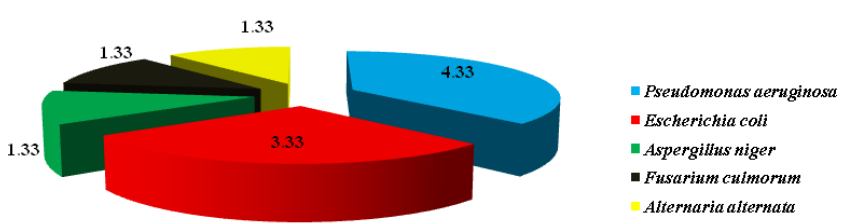

Figure 1 Antibacterial activity of Rosa canina flower ethanolic extract against microorganisms (in $\mathrm{mm}$ )

Result data of Hirulkar and Agrawal, 2010 showed that low dilution of alcoholic extract exhibited higher antimicrobial activity comparing with higher dilution. Petroleum and its extract showed maximum of $29 \mathrm{~mm}$ of inhibition zone for Pseudomonas aeruginosa in comparison to other bacterial strains. Alcoholic extract showed higher inhibitory effect on Streptococcus pneumoniae $(30 \mathrm{~mm}$ of inhibition zone), Enterobacter aerogens (28mm), Staphylococcus epidermidis $(25 \mathrm{~mm})$, Bacillus subtilis $(30 \mathrm{~mm})$, Pseudomonas aeruginosa $(32 \mathrm{~mm})$. Aqueous extract showed higher inhibition against E.coli $(21 \mathrm{~mm})$, Enterobacter aerogens (25mm) and Bacillus subtilis $(28 \mathrm{~mm})$ in comparison to other bacterial strains The zone of inhibition was higher to antibiotic at the highest concentration in the case of Streptococcus pneumoniae and Pseudomonas aeruginosa then the antimicrobial activity of Rose petals with control antibiotic compared. Study showed that the average relative antimicrobial activity was found the highest for alcoholic extract $(25 \mathrm{~mm})$, followed by aqueous $(19 \mathrm{~mm})$ and petroleum $(18 \mathrm{~mm})$.

Darokar et al. 1998 was found Gram-positive Bacillus subtilis strain ATCC 6015 and Gram-negative bacterium Pseudomonas aeruginosa ATCC 25668 strain to be the most sensitive to rose petals; and the petals of 18 varieties were active against ATCC 6015 and those of 13 varieties against ATCC 25668 Among the Gram-positive bacteria, Streptococcus mutans and Mycobacterium smegmatis were relatively more tolerant to rose petals compared to Staphylococcus epidermidis, S. aureus and B. subtilis. Among the Gram-negative bacteria, the strains of Escherichia coli, Enterococcus faecalis and Enterobacter aerogenes were more tolerant to rose petals compared to Klebsiella pneumoniae, Salmonella typhimurium and P. aeruginosa strains (Darokar et al., 1998).

In our study the best antimicrobial effect of methanolic extract of Rosa canina flower was found against Gram-negative microorganisms and especially agains Escherichia coli (Figure 2).
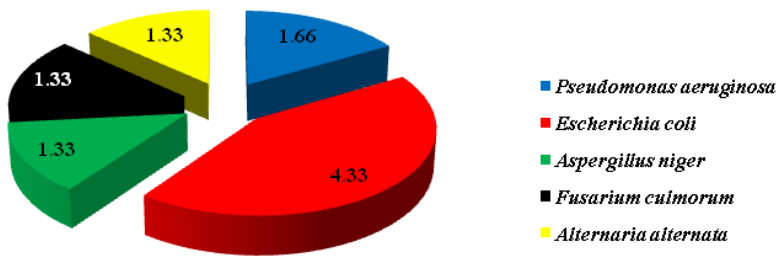

Figure 2 Antibacterial activity of Rosa canina flower methanol extract against microorganisms (in $\mathrm{mm}$ )

Ozturk Yilmaz and Ercisli, 2011 study clearly indicated that the methanolic extract of different Rosa taxa fruits has antibacterial activity against a number of bacteria and antibacterial activity was differed among taxa tested against bacteria Regarding the taxa tested, Rosa pisiformis extract inhibited the growth of Yersinia enterocolitica, Streptococcus aureus, Bacillus cereus and Salmonella typhimurium with 0-13 mm inhibition zone. Rosa canina extract inhibited the growth of Yersinia enterocolitica, Enterococcus faecalisand Bacillus cereus with 9-11 mm inhibition zone. Rosa villosa extract inhibited the growth of Enterococcus faecalis and Bacillus cereus with 10-12 mm inhibition zone. Rosa dumalis subsp. antalyensis extract inhibited the growth of Yersinia enterocolitica, Bacillus cereus and Klebsiella pneumoniae with 10-14 mm inhibition zone.

The Rosa canina fruit methanol extract at $\mathrm{MIC}=2.0 \mathrm{mg} / \mathrm{mL}$ was the mos effective against $S$. aureus and $C$. albicans. Also, with the exception of $B$. cereus, the water extract of Rosa canina demonstrated the antimicrobial activity against both Gram-positive and Gram-negative bacteria tested in this study, and the highest MIC was $3.5 \mathrm{mg} / \mathrm{mL}$. The antibacterial activity of the Rosa canina acetone extract was detected against $E$. coli, $S$. aureus and $C$. albicans. Furthermore, the chloroform and $n$-hexan extracts, even in the concentration of $10 \mathrm{mg} / \mathrm{mL}$, had no inhibition activity against all tested microorganisms (Montazeri et al., 2011).

The results obtained in Mishra et al. 2011 study showed that the leaves, stem and flower of Rosa indica (red) have bactericidal effect on pathogenic microorganisms. The methanolic extract showed better and improved antibacterial activity in comparison to ethyl acetate. The widest zone of inhibition $(18 \mathrm{~mm})$ was determined by the methanolic extract of Rosa indica petals, followed by leaves $(14 \mathrm{~mm})$ and stem $(17 \mathrm{~mm})$ extracts. A remarkable $13 \mathrm{~mm}$ zone of inhibition was recorded by ethyl acetate extract of Rosa indica stem against $P$. aeruginosa, while E. coli and $S$. aureus found insensitive. Similar type of investigations was reported earlier with ethanolic extracts (Sathiya et al., 2013).

\section{CONCLUSION}

The best antimicrobial effect of Rosa canina flower ethanolic extract was found against Pseudomonas aeruginosa and the best antimicrobial effect of Rosa canina flowers methanolic extract was found against Escherichia coli. Herbal medicines are valuable and readily available resource for primary health care and complementary health care systems. Undoubtedly, the plant kingdom still holds many species of plants containing substances of medicinal value that have yet to be discovered, though large numbers of plants are constantly being screened for their antimicrobial effects. These plants may prove to be a rich source of 
compounds with possible antimicrobial activity, but more pharmacological investigations are necessary.

Acknowledgments: The paper was supported by the project: The research leading to these results has received funding from the European Community under project no 26220220180: Building Research Centre „AgroBioTech“, by grant of VEGA 1/0611/14 and by grant of KEGA 012SPU-4/2013.

\section{REFERENCES}

DAROKAR, M. P., MATHUR, A., DWIVEDI, S., BHALLA, R., KHANUJA, S. P. S., KUMAR, S. 1998. Detection of antibacterial activity in the floral petals of some higher plants. Current Science, 75, 187-189.

DELIORMAN ORHAN, D., HARTEVIOLU, A., KÜPELI, E., YESILADA, E. 2007. In vivo anti-inflammatory and antinociceptive activity of the crude extract and fractionsfrom Rosa canina L. fruits. International Journal of Ethnopharmacology, 112, 394-400. http://dx.doi.org/10.1016/j.jep.2007.03.029

EGEA, I., SÁNCHEZ-BEL, P., ROMOJARO, F., PRETEL, M.T. 2010. Replace synthetic additives in functional foods as a natural antioxidant. Plant Foods for Human Nutrition. 65, 121-129.

FECKA, I. 2009. Qualitative and quantitative determination of hydrolysable tennins and other polyphenols in herbal products from meadowsweet and dog rosa. Phytochemical Analyses, 20, 177-190. http://dx.doi.org/10.1002/pca.1113

GHAZGHAZI, H., MIGUEL, M.G., HASNAOUI, B., SEBEI, H., KSONTINI, M., FIGUEIREDO, A.C., PEDRO, L.G., BARROSO, J.G. 2010.Phenols, essential oils and carotenoids of Rosa canina from Tunisia and their antioxidant activities. African Journal of Biotechnology, 9(18), 2709-2716.

CHRUBASIK, C., DUKE, R.K., CHRUBASIK, S. 2006. The evidence for clinical efficacy of rosa hip and seed: a systematic review. Phytotherapy Research, 20, 1-3. http://dx.doi.org/10.1002/ptr.1729

KERÉNYI-NAGY, V., BAKAY, L., BÖHM É. I. 2013. Adatok Hont vármegye rózsa, galagonya és körte flórájához : Rose, hawthorn and pear datas to Hont historical county. Hungarian Journal of Landscape Ecology, 11(2), 229-232.

KILICGUN, H., ALTINER, D. 2010. Correlation between effect mechanism and polyphenol content of Rosa canina. Pharmacognozy Magazine, 6, 238-241. http://dx.doi.org/10.4103/0973-1296.66943

KUMARASAMY, Y., COX, P.J., JASPARS, M., NAHAR, L., SARKER, S.D. 2002.Screening seeds of Scottish plants for antibacterial activity. Journal of Ethnopharmacology, 83, 73-77. http://dx.doi.org/10.1016/s0378-8741(02)00214.

SATHIYA, S., KARTHIKEYAN, B., CHERUTH, A.J., AZOOZ, M.M., IQBAL, M. 2008.Antibiogram of Catharanthus roseus extracts. Global Journal of Molecular Sciences,3(1), 01-07.

MISHRA, R.P., ARSHAD, M., SAMI, A. 2011. Antibacterial Properties of Rosa indica (L.) Stem, Leaves and Flowers. Journal of pharmaceutical and biomedical sciences, 2011, 12(15) 1-3

MONTAZERI, N., BAHER, E., MIRZAJANI, F., BARAMI, Z., YOUSEFIAN,

S. 2011. Phytochemical contents and biological activities of Rosa canina fruit from Iran. Journal of Medicinal Plants Research, 5(18), 4584-4589.

OZTURK YILMAZ, S., ERCISLI, S. 2011. Antibacterial and antioxidant activity of fruits of some rose species from Turkey. Romanian Biotechnological Letters, 16(4), 6407-6411.

QUAVE, C.L., PLANO, L.R.W., PANTUSO, T., BENNETT, B.C. 2008. Effects of extracts from Italian medicinal plants on plantonic growth, biofilm formation and adherence in MRSA. Journal of Ethnopharmacology, 118, 418-428. http://dx.doi.org/10.1016/j.jep.2008.05.005

REIN, E., KHARAZMI, A., WINTHER, K. 2004. A herbal remedy, Hyben vital (stand. powder of a subspecies of Rosa canina fruits) reduces pain and improves general wellbeing in patients with osteoarthritis-a double-blind, placebocontrolled, randomized trial. Phytomedicine 11, 383-391.

ROSSNAGEL, K., WILLICH, S.N. 2001. Value of complementary medicine exemplified by rose-hips. Gesundheitswesen, 63(6), 412-6

SERTESER, A., KARGIOGLU, M., GÖK, V., BAGCI, Y., ÖZCAN, M.M., ARSLAN, D. 2008. Determination of antioxidant effects of some plant specie wild growing in Turkey. International Journal of Food Sciences Nutrition, 59, 643-651. http://dx.doi.org/10.1080/09637480701602530

SHIOTA, S., SHIMIZU, M., MIZUSIMA, T.,ITO, H., HATANO, T., YOSHIDA, T., TSUCHIYA, T.2000. Restoration of effectiveness of betalactams on methicillin-resistant Staphylococcus aureus by tellimagrandin I from rose red. FEMS Microbiology Letters, 185, 135-138.

SHIOTA, S., SHIMIZU, M., SUGIYAMA, J., MORITA, Y., MIZUSHIMA, T., TSUCHIYA, T. 2004.Mechanisms of action of corilagin and tellimagrandin I that remarkably potentiate the activity of beta-lactams against methicillin-resistant Staphylococcus aureus. Microbiology and Immunology,48, 67-73. http://dx.doi.org/10.1111/j.1348-0421.2004.tb03489.x
Trovato, A., MONFORTE, M.T., FORESTIERI, A.M., PIZZIMENTI,F 2000. In vitro anti-mycotic activity of some medicinal plants containing flavonoids.Bollettino Chimico Farmaceutico, 139, 225-227.

TROVATO, A., MONFORTE, M.T., ROSSETTO, A., FORESTIERI, A.M 1996. In vitro cytotoxic effect of some medicinal plants containingflavonoids.BollettinoChimicoFarmaceutico, 135, 263-266.

WENZIG, E.M., WIDOWITZ, U., KUNERT, O., CHRUBASIK, S., BUCAR, F. KNAUDER, E., BAUER,R. 2008. Phytochemical composition and in vitro pharmacological activity of two rose hip (Rosa canina L.) preparations Phytomedicine, 15, 826-835. http://dx.doi.org/10.1016/i.phymed.2008.06.012 